\title{
Nadir Bir Olgu; Akut Retansiyona Bağlı Spontan Mesane Perforasyonu
}

\section{A Rare Case; Spontaneous Bladder Rupture due to Acute Retention}

\author{
Alkım Tolga VAROL, Orkun BATMAZ, Ahmet Ender CAYLAN, Murat UÇAR, Ahmet DANIȘMAN
}

Akdeniz Üniversitesi Tıp Fakültesi, Üroloji Anabilim Dalı, Antalya, Türkiye

Yazışma Adresi

Correspondence Address

Alkim Tolga VAROL

Akdeniz Üniversitesi Tip

Fakültesi, Üroloji Anabilim Dalı,

Antalya, Türkiye

atolgavarol@gmail.com

Geliş tarihi / Received :Haz 01, 2020

Kabul tarihi / Accepted : Haz 22, 2020

Elektronik yayın tarihi : Eyl 01, 2021

Online published

Bu makalede yapılacak atıf:

Cite this article as:

Varol A.T, Batmaz O, Caylan A.E,

Uçar M, Danışman A.

Nadir Bir Olgu; Akut Retansiyona

Bağlı Spontan

Mesane Perforasyonu

Akd Tip D / 2021; 7(3):474-478

Alkım Tolga VAROL

ORCID ID: 0000-0002-4378-1666

Orkun BATMAZ

ORCID ID: 0000-0003-3924-2325

Ahmet Ender CAYLAN

ORCID ID: 0000-0003-1053-915X

Murat UÇAR

ORCID ID: 0000-0001-6977-7430

Ahmet DANIŞMAN

ORCID ID: 0000-0002-6367-9853

\section{ÖZ}

Mesane perforasyonları, nadir görülen ve intraperitoneal olduğu takdirde, hayatı tehdit edici boyuta ulaşabilen ürolojik acil cerrahi gerektiren durumlardan biridir. Nonspesifik semptomatolojisi ve nadir görülmesi nedeniyle tanıyı doğru koymak ve tedavisini planlamak zaman alabilmektedir. Burada bir olgu üzerinden intraperitoneal mesane perforasyonunun tanı, tedavi ve takip süreçlerinin hatırlanması amaçlanmıştır.

\section{Anahtar sözcülkler}

Mesane perforasyonu, Mesane rüptürü, Üriner sistem hastalıkları, Ürolojik cerrahi

\begin{abstract}
Spontaneous bladder perforation is a rare life threatening condition requires urgent surgery in which case it is intraperitoneal. Due to its nonspecific symptomatology and it's rarity, establishing the true diagnosis and planning it's treatment might take time. In this paper, based on a case, it is aimed to recapture the diagnosis, treatment and follow-up processes of intraperitoneal bladder perforations.
\end{abstract}

\section{Key words}

Bladder perforation, Bladder rupture, Urinary tract disorders, Urological surgery

\section{GíRiş}

Rutin üroloji pratiğinde skk karşılaşılmayan bir ürolojik acil olan spontan mesane perforasyonunun insidans1 126.000 'de 1 olup mortalitesi \%47'ye kadar ulaşabilmektedir (1). Mesane perforasyonu çoğunlukla (\%82) araç içi trafik kazası, yüksekten düşme gibi yüksek enerjili künt kemik pelvis travmasına bağlı oluşmaktadır (2). Eksternal travmalar dışında mesane perforasyonu kronik sistit, mesane karsinomu, tüberküloz, kronik mesane kateterizasyonu, akut üriner retansiyon, dev mesane taşı gibi patolojilere bağlı olarak da görülebilmektedir (2-5). Spontan mesane perforasyonu tüm perforasyonların \%1'ini oluşturmaktadır (1). Tüm mesane perforasyonlarının 2/3'ü ekstraperitoneal iken, sadece 1/3'ü intraperitoneal olarak görülmektedir (3). Bu olgu sunumu ile spontan intraperitoneal mesane perforasyonu tanılı bir erkek hastada tanı ve tedavi süreçlerini sunmayı planladık. 
Varol A.T. ve ark.

\section{OLGU SUNUMU}

54 yaşında erkek hasta son 6-7 saattir idrar yapamama ve sonrasında ani başlayan şiddetli karın ağrısı nedeniyle ikinci basamak sağlık kuruluşu acil servisine başvurmuş. Hastanın yaklaşık üç yıldır hafif-orta derecede obstrüktif alt üriner sistem şikayetleri varmış; bu nedenle alfuzosin tedavisi almış ancak son altı aydır tedaviye devam etmiyormuş. Hastanın yakın zamanda geçirilmiş travma öyküsü yokmuş. Hasta non invaziv yüksek dereceli ürotelyal mesane karsinomu tanısı ile son iki yıldır semptomsuz ve nükssüz bir halde takip edilmekteymiş. Hastaya ilk başvurduğu sağlık kuruluşunun acil servisinde üretral foley sonda takılmış, idrar çıkışı gözlenmiş ve üroloji hekimiyle konsülte edilmeden taburcu edilmiş. Ancak karın ağrısı geçmeyen hasta tekrar aynı kurumun acil servisine başvurmuş ve orada yapılan opaklı abdominal tomografide üretral sonda balonunun mesane dışında olduğu ve mesane dışına opak ekstravazasyonu varlığı fark edilerek mesane perforasyonu ön tanısıyla üçüncü basamak sağlık kuruluşu olan hastanemiz acil servisine yönlendirilmiş.

Acil serviste tarafimızca alınan anamnez ve yapılan muayenesinden; hastanın karın ağrısının devam ettiği, üç gündür gaz

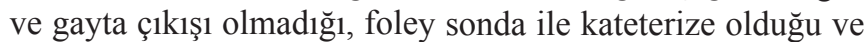
idrar torbasında bir miktar açık renkli idrar olduğu tespit edildi. Ayrıca fizik muayenesinde batında yaygın hassasiyet, defans, rebound ve distansiyon da mevcuttu.

Hastanın biyokimyasal değerlendirilmesinde, bazal serum kreatinin değerlerinin normal sınırlarda olduğu öğrenilen hastanın acil servisteki serum kreatinin değeri $2,25 \mathrm{mg} / \mathrm{dl}$ (Normal değer aralığ1: 0,7-1,3 mg/dl), hemoglobin değeri 12 $\mathrm{mg} / \mathrm{dl}$ (Normal değer aralığı: 12-16 mg/dl) ölçüldü. Acil serviste ölçülen vücut $1 \mathrm{~s} 1 \mathrm{~S} 137^{\circ} \mathrm{C}$, kan beyaz küre sayısı 19780/dl (Normal değer aralığ1: 3910-8770/dl) ve C- reaktif protein $0,78 \mathrm{mg} / \mathrm{dl}$ (Normal değer aralığı: 0-0,5 mg/dl) olarak saptand1.

İkinci basamak sağlık kuruluşunda yapılan oral opaklı tomografi tarafımızca tekrar değerlendirildi. Mesane lümeni ve bağırsak ansları arasında kontrast madde görüldü ve foley sonda sakroiliak eklem seviyesine kadar peritoneal kavite içinde izlendi (Şekil 1, 2).

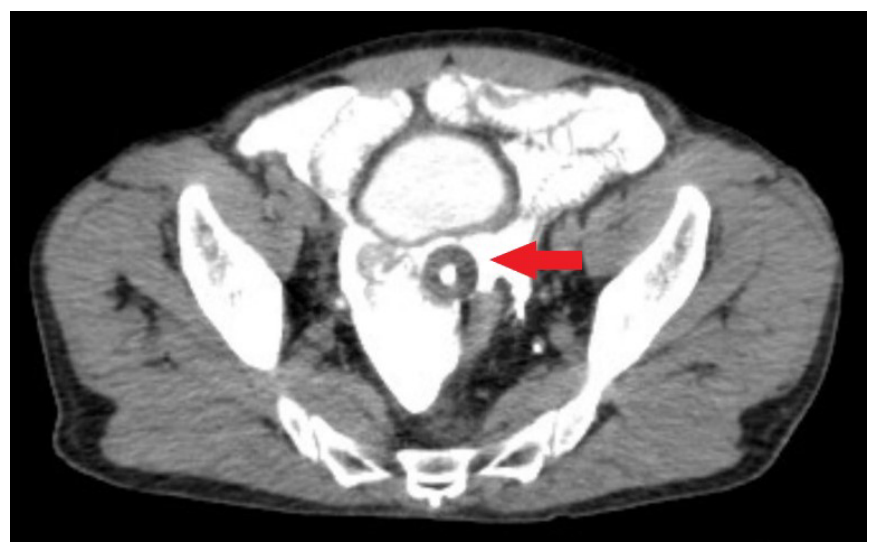

Şekil 1: Oral opaklı bilgisayarlı tomografide transvers kesitte sonda balonu ve intraperitoneal alana opak ekstravazasyonu (ok)

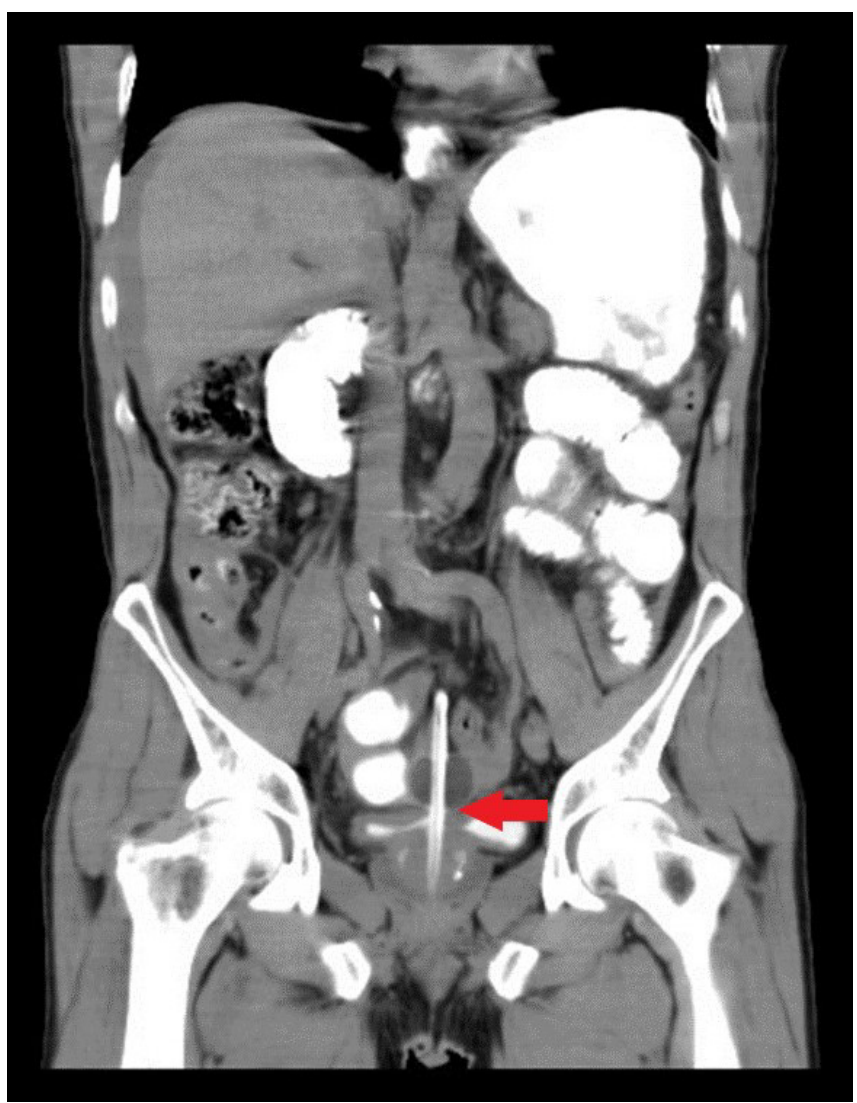

Şekil 2: Abdominal tomografide koronal kesitte sonda balonu mesane dışında, iliak çapraz seviyesinde görülüyor (ok)

Hastaya tarafimızca uygulanan retrograd sistografide mesanenin kubbesinden intraperitoneal alana opak ekstravazasyonu izlendi (Şekil 3).

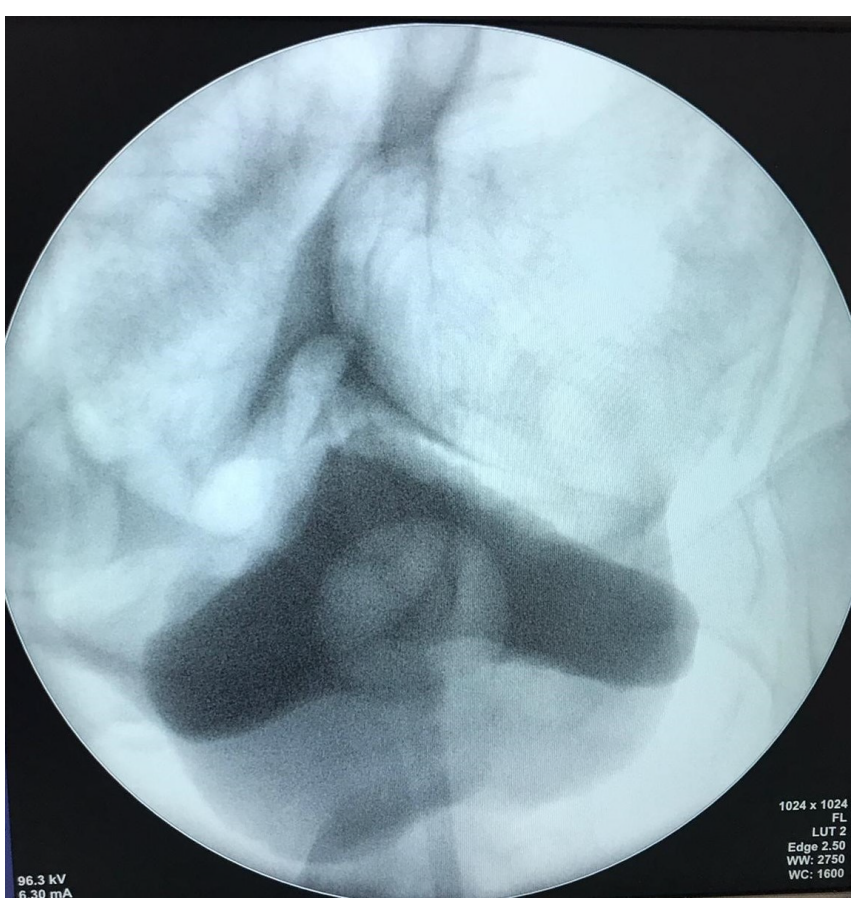

Şekil 3: Sistografide opak ekstravazasyonu gözleniyor 
Olgunun özgeçmişinde mesane tümörü öyküsü olduğu için ilk olarak fleksibl sistoskopi yapıldı. Mesane içerisinde tümör odağ1 izlenmedi ve mesane kubbesinde 2-2,5 cm çapında perforasyon alanı görüldü (Şekil 4).

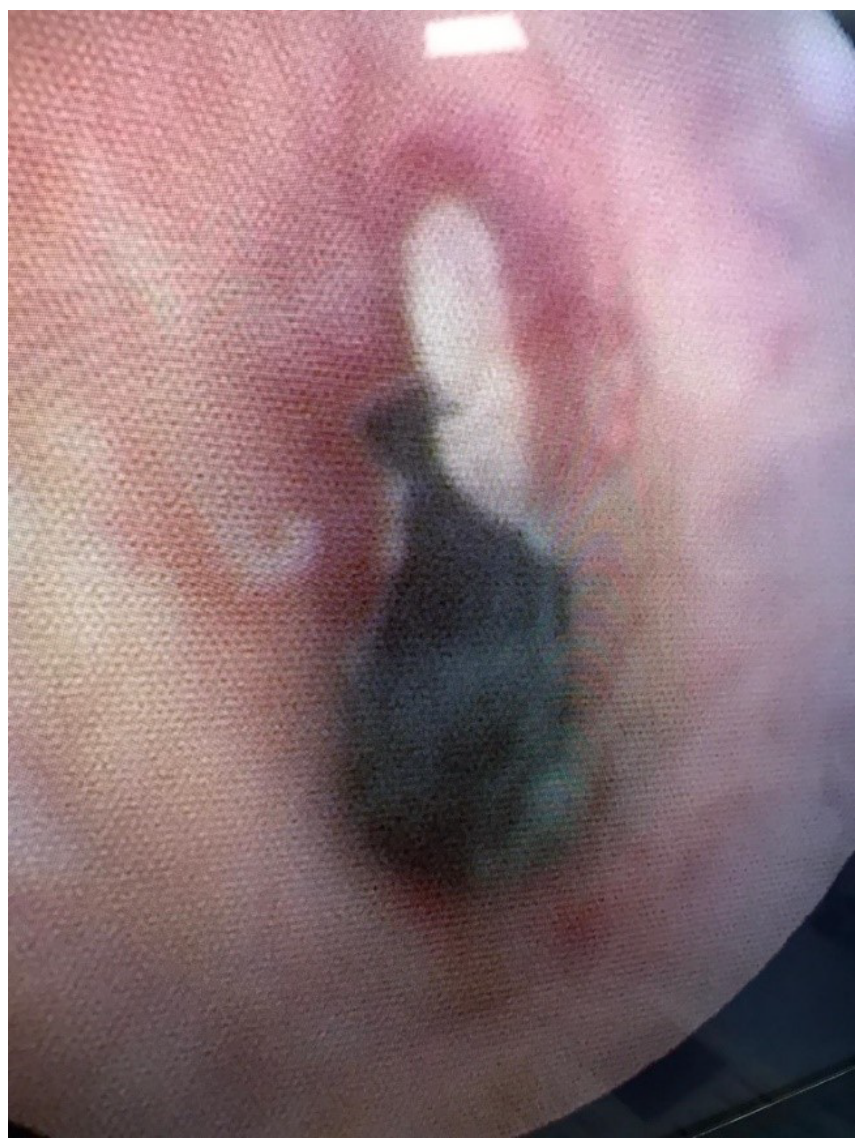

Şekil 4: Mesane kubbede yaklaşık 2 cmlik perforasyon alanı (perioperatif görüntü)

İntraperitoneal mesane perforasyonu tanısı düşünülerek hastaya laparotomi yapılması kararı alındı. Açık onarım amaçlı göbek alt1 $10 \mathrm{~cm}$ 'lik insizyon yapıldı, barsak ansları arasındaki bol miktarda sıv1 aspire edildi. İntraoperatif bakıda mesane kubbe yerleşimli perforasyon alanı görüldü. Yara kenarları belirlendikten ve sağlıklı doku ortaya çıkarıldıktan sonra mesane iki kat su sızdırmaz olacak şekilde 2-0 poliglaktin sutur ile repare edildi. Bakıda intraperitoneal alanda başka patoloji saptanmadı. Batın içi distile su ile yıkandı, kanama kontrolü sonrası loja bir adet kauçuk dren, üretral 20 French foley sonda konarak operasyon sonlandirıldı.

Hastanın servis takibinde idrar çıkışı günlük yaklaşık $2000 \mathrm{cc}$ idi ve aldığ 1 sıvı ile uyumluydu. $38^{\circ} \mathrm{C}$ 'yi geçen ateşi olması üzerine idrar, kan ve balgam kültürü alındı ve enfeksiyon hastalıkları ile konsülte edilerek peritonit/ ürosepsis öntanısıyla intravenöz meropenem tedavisi başlandı.

Postoperatif 1. günde rektal gaz çıkışı oldu. Serum kreatinin değeri postoperatif birinci günde $1,28 \mathrm{mg} / \mathrm{dl}$, postoperatif ikinci günde $0,69 \mathrm{mg} / \mathrm{dl}$ 'e geriledi. Alınan tüm kültürler steril olarak sonuçlandi. Postoperatif 7. günde yapılan retrograd sistografide mesane konturları düzenliydi, sağ böbreğe grade 4 reflü olduğu görüldü ve opak ekstravazasyonu izlenmediği için hastanın sondası çekildi (Şekil 5).

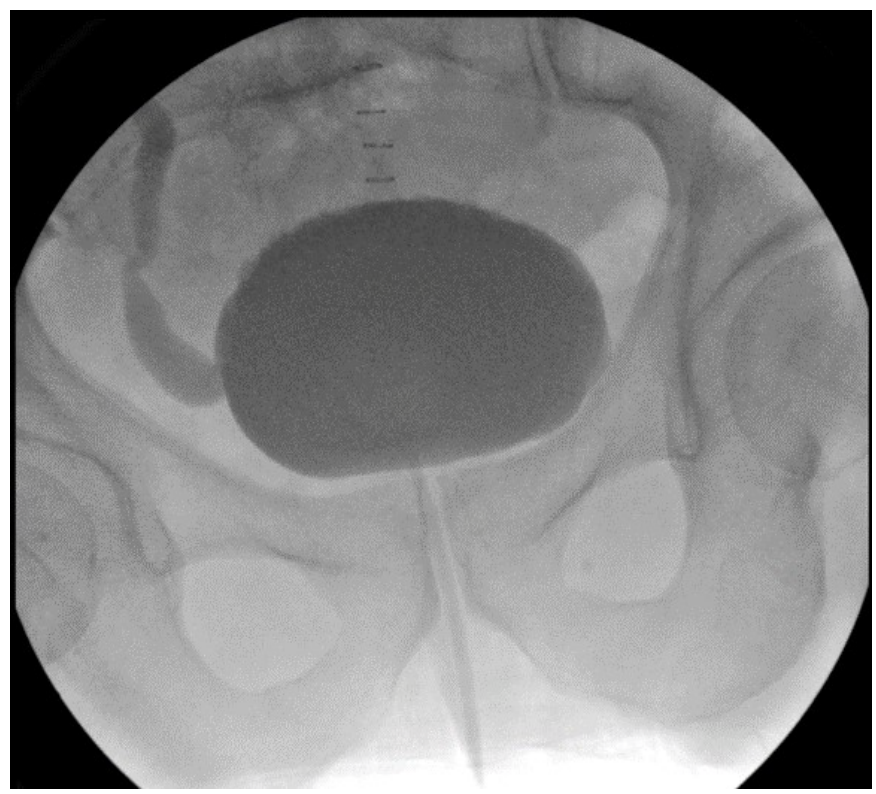

Şekil 5: Postoperatif 7. günde yapilan sistografide mesanede ekstravazasyon yok ancak sağ vezikoüreteral reflü görülüyor

Hastaya sonda çekildikten sonra yapılan üroflowmetride işeme eğrisinin çan eğrisi şeklinde olduğu ve mesanede rezidüel idrar kalmadığı görüldü (Şekil 6).

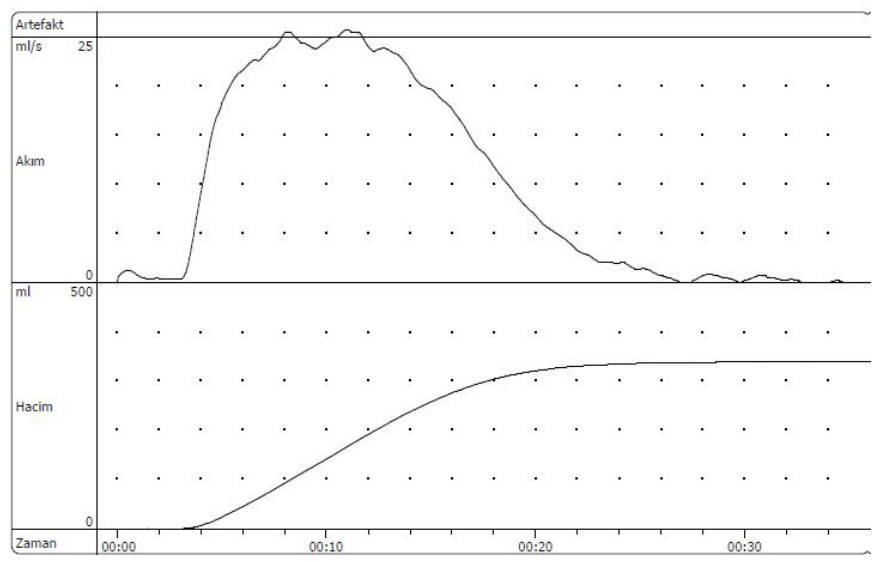

Şekil 6: Hastanın sondası çekildikten sonra yapılan üroflowmetri

Hastanın uluslararası prostat semptom skorunun (IPSS) 19 olması üzerine alfuzosin tedavisine tekrar başlandı. Hastanın üretral sondası çekildikten sonraki 7. günde yapılan kontrol tüm batın ultrasonografisinde batın içinde serbest sıvı saptanmadı, üst üriner sistem normaldi, prostat yaşı ile uyumlu büyüklükte ve mesanesi trabeküle olarak raporlandi. Hastadan bu olgu sunumu için bilgilendirilmiş onam formu alınmıştır. 


\section{TARTIŞMA}

Literatüre bakıldığında nadir görülen bir klinik tablo olan mesane perforasyonu en sık travmaya bağlı gelişmektedir (6). Künt abdominal travmaların yaklaşık \%1,6'sında mesane yaralanması görülür (7). Mesane perforasyonu travma dişında ise mesane tümörlerinin veya mesane taşlarının endoskopik tedavisi, jinekolojik müdahaleler ve genel cerrahi müdahaleleri esnasında mesane duvarının hasar görmesi ile meydana gelmektedir. Daha az sıklıkta ise mesane malignitesi, mesane divertikülü, sistit, pelvik radyoterapi, diabetes mellitus, nöropatik mesane gibi nedenler sorumlu tutulmaktadır $(8,9)$. Altta yatan künt veya penetran bir travma olmadığında tanımlanan spontan mesane rüptürü oldukça nadir görülen bir ürolojik acil durumdur.

Mesane perforasyonlarının çoğunun anatomik lokalizasyonu mesane kubbesinden olmaktadır (6). Bu vakada var olan tedaviye dirençli ateş, batında yaygın hassasiyet, defans gibi bulgular şimik veya bakteriyel peritonitin bir sonucu olarak değerlendirilebilir. Mesane perforasyonu erken safhada bulgu vermeyebilir. En sık görülen bulgular olarak karında distansiyon, epigastriumda ağrı ve ateş sayılabilmektedir (9). Hastaların bir kısmı makroskopik hematüri ile de prezente olmaktadır ancak hastaların \%1 kadarında sadece mikroskobik hematüri görülebilmektedir (3). İntraperitonal ruptürlerde peritondan idrar absorbsiyonu olması ile ilerleyen dönemde BUN (kan üre nitrojeni) ve serum kreatinin değerlerinde artış görülebilmektedir $(6,12)$. Bu hastayı acil servise getiren nedenin idrar yapamama ve yaygın karın ağrısı olduğu görülmektedir. Perforasyonun ilk aşamasında, rüptürün klinik belirtileri minimal ve non-spesifik olabilir. Böyle bir prezentasyon tanıda gecikmeye neden olabilir ve diğer abdominal patolojilerle karıştırılabilir (13). $\mathrm{Bu}$ nedenle spontan mesane perforasyonunda şüphe klinik tanı için elzemdir. Mesane ruptüründen şüphelenildiği takdirde BT sistografi veya pelvik travma öyküsü olmayan stabil hastada retrograd sistografi tanı için en iyi yol göstericidir (8). Nadir bir durum olan bu patoloji eğer tedavisiz kalırsa mortalite \%34'lere çıkabilmektedir (14).

Literatürde sadece üretral kateterizasyon sonrası mesane ruptürü bildiren olguların yanı sıra mesane taşına sekonder mesane perforasyonu bildiren olgu sunumları da mevcuttur $(5,10)$. Bu hastada her ne kadar alt üriner sistem

obstrüksiyonu hikayesi olsa da yakın zamanda medikal tedaviye ihtiyaç duymaması yanında cerrahi tedavi sonrası üretral sonda çekildikten sonra yapılan üroflowmetride işeme eğrisinde obstrüksiyon görülmemesi ve mesanede rezidüel idrar kalmaması kronik üriner retansiyona bağlı perforasyon ihtimalinden bizi uzaklaştırmıştır.

Her ne kadar literatürde mesane karsinomunun ruptüre predispozan faktör olduğu vaka sunumlarıyla gösterilmiş olsa da (11) sunulan hastanın son iki yıldır tümör nüksü olmaması, sistoskopisinde mesane tümörü görülmemesi ve mesane karsinomu nedenli aktif tedavi görmemesi bu olasılı̆̆ azaltmaktadır. Sunulan hastada da perforasyonun en sik sebebi olan travma öyküsünün olmaması ve tüm bu olasılıklar değerlendirildiğinde mesane ruptürüne tek başına nadiren yol açabilecek birkaç farklı durum burada eş zamanlı birlikte bulunarak mesane perforasyonuna sebep olduğu yorumunu yapmanın yanlış olmayacağını düşünüyoruz.

Avrupa Üroloji Derneği (EAU) kılavuzuna göre çoğu ekstraperitoneal ruptürlerde konservatif yaklaşım, intraperitoneal ruptürde ise idrar ekstravazasyonunun yol açtığı peritonit ve olası sepsis riski nedeniyle cerrahi tedavi önerilmektedir (15). $\mathrm{Bu}$ vakada tomografide intraperitoneal mesane ruptüründen şüphelenmemize rağmen cerrahi gerekmeksizin konservatif yaklaşımla sürecin yönetilebilirliğini anlayabilmek için sistografi yapıldı. Sistografide de geniş perforasyon ve belirgin ekstravazasyon saptanması nedeniyle hastaya zaman kaybetmeden cerrahi tedavi planland 1 ve uyguland.

\section{SONUÇ}

Spontan mesane perforasyonu nadir görülen, değerlendirilmesi zor ve tanıda yaşanan gecikmelerin sonuçları itibariyle hayatı tehdit edebilecek boyuta ulaşabilen ürolojik bir acildir. Spesifik tanı metodu olmamakla birlikte şüphe halinde BT sistografi veya retrograd sistografi tekniği seçilmeli ve intraperitoneal mesane ruptüründe cerrahi tedavi ön planda değerlendirilmelidir.

Çıkar Çatışması ve Finansal Destek Bildirimi: Yazarlar bu olgu sunumu ile ilgili olarak herhangi bir çıkar çatışması bildirmemiştir. Çalışmamız için hiçbir kurum ya da kişiden finansal destek alınmamıştır.

Hasta onamı: Hastadan bu olgu sunumu için bilgilendirilmiş onam formu alınmıştır.

Yazar Katkıları: Çalışmanın konsepti ve dizaynı: OB, AEC, MU; verilerin toplanması, yorumlanması: ATV, OB; literatür araştırması: ATV, OB, AEC; Makalenin yazımı: ATV, OB, AEC; Kritik gözden geçirme: AEC, MU, AD 


\section{KAYNAKLAR}

1. Hansen HJ, Eldrup J. Spontaneous rupture of the urinary bladder--a late complication toradiotherapy. Case report. Scand J Urol Nephrol 1989; 23(4): 309-310.

2. Morey AF. Iatrogenic bladder perforations: longterm followup of 65 patients. J Urol 2005; 174(4):1299.

3. Phillips B, Holzmer S, Turco L, Mirzaie M, Mause E, Mause A, Person A, Leslie SW, Cornell DL, Wagner M, Bertellotti R, Asensio JA. Trauma to the bladder and ureter: a review of diagnosis, management, and prognosis. Eur J Trauma Emerg Surg 2017; 43(6):763-773.

4. Murata R, Kamiizumi Y, Tani Y, Ishizuka C, Kashi wakura S, Tsuji T, Kasai H, Haneda T, Yoshida T, Katano H, Ito K. Spontaneous rupture of the urinary bladder due to bacterial cystitis. J Surg Case Rep 2018; 2018(9):rjy253.

5. Salar R, Özbay E, Karlıdağ İ, Durmuş E, Öncel HF, Özyuvalı E, Yenigürbüz S, Yalçın M. Dev Mesane Taşına Bağlı Spontan Mesane Perforasyonu: Olgu Sunumu. Van Tip Derg 2017; 24(3): 188-190

6. Simon LV, Sajjad H, Lopez RA, Burns B. Bladder Rupture. In StatPearls Treasure Island (FL); 2020

7. Morey AF, Brandes S, Dugi DD 3rd, Armstrong JH, Breyer BN, Broghammer JA, Erickson BA, Holzbeierlein J, Hudak SJ, Pruitt JH, Reston JT, Santucci RA, Smith TG 3rd, Wessells H; American Urological Assocation. Urotrauma: AUA guideline. J Urol 2014; 192(2):327- 335.

8. Crawford R, Oliver TRW, Abboudi H, Shah S. Spon taneous rupture of the bladder during vomiting. BMJ Case Rep 2017; bcr2016217914.
9. Peters PC. Intraperitoneal rupture of the bladder. Urol Clin North Am 1989; 16(2):279- 282.

10. Poola S, Mohan A. A Foley Fallacy: A Case of Bladder Rupture after "Routine" Foley Catheter Placement. Case Rep Urol 2018; 2018:7978126.

11. Lee JH, You HW, Lee CH. Spontaneous Intraperito neal Bladder Perforation Associated with Urothelial Carcinoma with Divergent Histo logic Differentiation, Diagnosed by CT Cystography. Korean J Urol 2010; 51(4):287-290.

12. Mahat Y, Leong JY, Chung PH. A contemporary review of adult bladder trauma. J Inj Violence Res 2019;11(2):101-106.

13. Muneer M, Abdelrahman H, El-Menyar A, Zarour A, Awad A, Al-Thani H. Spontaneous Atraumatic Urinary Bladder Rupture Secondary to Alcohol Intoxication: A Case Report and Review of Litera ture. Am J Case Rep 2015;16:778- 781.

14. Kong JP, Bultitude MF, Royce P, Gruen RL, Cato A, Corcoran NM. Lower urinary tract injuries following blunt trauma: a review of contemporary manage ment. Rev Urol 2011;13(3):119-130.

15. Kitrey N D, Djakovic N, Hallscheidt P, Kuehhas F E, Lumen N, Serafetinidis E, Sharma D M, Abu-Gha nem Y, Sujenthiran A, Waterloos M. EAU Guide lines. Edn. presented at the EAU Annual Congress, Amsterdam, the Netherlands, 2020. ISBN 978-94-92671-07-3. 